\title{
COVID-19 transmission in a university setting: a rapid review of modelling studies
}

\author{
Hannah Christensen ${ }^{1 *}$, Katy Turner ${ }^{2 *}$, Adam Trickey ${ }^{1}$, Ross D. Booton ${ }^{2}$, Gibran Hemani, Emily \\ Nixon $^{3}$, Caroline Relton ${ }^{1}$, Leon Danon ${ }^{4,5}$, Matthew Hickman ${ }^{1}$, Ellen Brooks-Pollock ${ }^{2}$. Part of \\ the University of Bristol UNCOVER group.
}

\author{
*Joint first authors \\ ${ }^{1}$ Bristol Medical School: Population Health Sciences, University of Bristol, Bristol, BS8 2BN, United Kingdom \\ and NIHR Health Protection Research Unit in Behavioural Science and Evaluation at University of Bristol \\ ${ }^{2}$ Bristol Veterinary School, University of Bristol, Bristol, BS40 5DU, United Kingdom and NIHR Health \\ Protection Research Unit in Behavioural Science and Evaluation at University of Bristol \\ ${ }^{3}$ School of Biological Sciences, University of Bristol, Bristol Life Sciences Building, 24 Tyndall Avenue, \\ Bristol, BS8 1TQ. \\ ${ }^{4}$ Computer Science, University of Exeter, Exeter, EX4 4QF. \\ ${ }^{5}$ Alan Turing Institute, British Library, 96 Euston Road, London NW1 2DB. \\ Correspondence to: Hannah Christensen PhD. Bristol Medical School: Population Health Sciences, University \\ of Bristol, Bristol, BS8 2BN, United Kingdom and NIHR Health Protection Research Unit in Behavioural \\ Science and Evaluation at University of Bristol Hannah.christensen@bristol.ac.uk
}

\begin{abstract}
Managing COVID-19 within a university setting presents unique challenges. At the start of term, students arrive from geographically diverse locations and potentially have higher numbers of social contacts than the general population, particularly if living in university halls of residence accommodation. Mathematical models are useful tools for understanding the potential spread of infection and are being actively used to inform policy about the management of COVID-19. Our aim was to provide a rapid review and appraisal of the literature on mathematical models investigating COVID-19 infection in a university setting. We searched PubMed, Web of Science, bioRxiv/ medRxiv and sought expert input via social media to identify relevant papers. BioRxiv/ medRxiv and PubMed/Web of Science searches took place on 3 and 6 July 2020, respectively. Papers were restricted to English language. Screening of peer-reviewed and pre-print papers and contact with experts yielded five relevant papers - all of which were pre-prints. All models suggest a significant potential for transmission of COVID-19 in universities. Testing of symptomatic persons and screening of the university community regardless of symptoms, combined with isolation of infected individuals and effective contact tracing were critical for infection control in the absence of other mitigation interventions. When other mitigation interventions were considered (such as moving teaching online, social/physical distancing, and the use of face coverings) the additional value of screening for infection control was limited. Multiple interventions will be needed to control infection spread within the university setting and the interaction with the wider community is an important consideration. Isolation of identified cases and quarantine of contacts is likely to lead to large numbers of students requiring educational, psychological and behavioural support and will likely have a large impact on the attendance of students (and staff), necessitating online options for teaching, even where in-person classes are taking place. Models were highly sensitive to assumptions in the parameters, including the number and type of individuals' contacts, number of contacts traced, frequency of screening and delays in testing. Future models could aid policy decisions by considering the incremental benefit of multiple interventions and using empirical data on mixing within the university community and with the wider community where available. Universities will need to be able to adapt quickly to the evolving situation locally to support the health and wellbeing of the university and wider communities.
\end{abstract}

NOTE: This preprint reports new research that has not been certifjed by peer review and should not be used to guide clinical practice. Keywords: COVID-19, Pandemic, Mathematical Modelling, University, UNCOVER group 
medRxiv preprint doi: https://doi.org/10.1101/2020.09.07.20189688; this version posted September 9, 2020. The copyright holder for this

preprint (which was not certified by peer review) is the author/funder, who has granted medRxiv a license to display the preprint in

It is made available under a CC-BY 4.0 International license.

COVID-19 transmission in a university setting: a rapid review of modelling studies

\section{Introduction}

As COVID-19 continues to circulate in the population, universities are looking to decide how to keep students, staff and the wider community safe, while providing a high-quality experience for students. Educational settings are associated with a high number of social interactions and may be important drivers of transmission for COVID-19. At the present time a low proportion of the student population are expected to have been infected with SARS-CoV-2, this fact along with the characteristics and behaviours of student populations poses a real risk of rapidly increasing case numbers at the start of the academic term. This in turn presents challenges in preparation for, and ongoing management of, COVID-19 within a university setting. Students travel from all over the UK and abroad to attend university. Most are between 18-24 years of age and many live in large shared multi-occupancy households or university halls of residence (mainly in first year). Although this age group are at relatively low risk severe complications and death from COVID-19, evidence from the Office for National Statistics serosurvey ${ }^{1}$ shows that they have similar or higher levels of infection compared with other age groups and could, therefore, pass on the infection to university staff and the wider community who may be at higher risk of serious COVID-19 outcomes.

Mathematical models are currently being used to help understand the evolving COVID-19 pandemic and to inform prevention and control strategies. In the absence of a vaccine, a number of other mitigation interventions could be relevant in a university setting, including, but not limited to: face coverings, social/ physical distancing, replacing large group teaching (i.e. in traditional lecture theatres) with online learning, minimising contacts through "bubbles" for small group taught work or in accommodation, reduction or elimination of field work, testing on arrival on campus, regular individual or pooled testing, self-isolation (for those symptomatic, testing positive, or close contacts of a case), education to recognise possible symptoms, handwashing/hand sanitiser, increased ventilation, reduced occupancy of staff and students on campus, and increased cleaning. These interventions could have a varying impact on COVID-19 cases and require different resources to support them. Some UK universities are planning for students to return to campus in autumn 2020 in a blended teaching model, for example with large lectures replaced with online teaching and small group practicals delivered as physically distanced. Other UK universities are considering alternative teaching models, including some planning fully online delivery for at least the first semester (October 2020 - January 2021).

Here we provide a rapid review of both the peer-reviewed and pre-print literature on mathematical models of COVID-19 (SARS-CoV-2) infection in the university or college community. We consider models describing infection spread in the absence of intervention and those comparing different scenarios of control strategies; any intervention for COVID-19 control is considered. We provide a summary of the methodological features and principal outcomes from the models, in terms of number of cases and effectiveness of interventions in reducing spread of COVID-19 in this setting, and recommendations on key interventions for COVID-19 control.

\section{Methods}

This paper was prepared in accordance with the PRISMA guidelines ${ }^{2}$. We searched PubMed, Web of Science, bioRxiv, and medRxiv to identify papers, in English, reporting mathematical models of coronavirus (COVID-19) in a university setting. PubMed and Web of Science searches took place on 6 July 2020; BioRxiv/medRxiv searches took place on 3 July 2020. The search criteria are presented in Table 1. We also sought expert input to locate pre-prints and grey literature via social media (twitter). The results of searches were screened for inclusion by HC and KT initially on the title and abstract, then full text. Papers were included if they described a mathematical model of COVID-19 infection within a university or college setting, in any geographical location. An updated version of one paper was obtained directly from the author ${ }^{3}$. Information was extracted from the included papers 
medRxiv preprint doi: https://doi.org/10.1101/2020.09.07.20189688; this version posted September 9, 2020. The copyright holder for this preprint (which was not certified by peer review) is the author/funder, who has granted medRxiv a license to display the preprint in

perpetuity.
It is made available under a CC-BY 4.0 International license.

COVID-19 transmission in a university setting: a rapid review of modelling studies

by several members of the team (HC, RDB, AT, EN, GH). This information (detailed in Table 2) included the focus and principal finding of the paper, model type and structure, population modelled, interventions considered, and selected COVID-19 infection related parameters. We did not seek to formally assess risk of bias in the included studies; there is no validated risk of bias assessment for modelling studies. Results were summarised through a descriptive synthesis of each study using text and tables.

Table 1. Search terms for the rapid review

\begin{tabular}{ll}
\hline Database & Search \\
\hline PubMed* & $\begin{array}{l}\text { All fields } \\
\text { Search: "student AND university AND infectious disease AND } \\
\text { mathematical model" } \\
\\
\text { Date range: unrestricted }\end{array}$ \\
\hline Web of Science & $\begin{array}{l}\text { All fields } \\
\text { Search: "Mathematical model AND COVID AND University" } \\
\text { Date range: unrestricted }\end{array}$ \\
\hline bioRxiv and medRxiv & $\begin{array}{l}\text { Full text or abstract or title (match whole all) } \\
\text { Search: "model* and (university or universities or campus) and } \\
\text { (coronavirus or COVID* or sars*)" } \\
\text { Date range: posted between "01 Dec, 2019 and 03 Jul, 2020" }\end{array}$ \\
\hline $\begin{array}{l}\text { *An initial search of PubMed including (COVID or coronavirus or SARS) did not return any hits, so a wider } \\
\text { search was included to identify potentially relevant papers considering other infectious disease models of } \\
\text { campus transmission. }\end{array}$ \\
\hline
\end{tabular}


medRxiv preprint doi: https://doi.org/10.1101/2020.09.07.20189688; this version posted September 9, 2020. The copyright holder for this preprint (which was not certified by peer review) is the author/funder, who has granted medRxiv a license to display the preprint in

perpetuity.
It is made available under a CC-BY 4.0 International license .

COVID-19 transmission in a university setting: a rapid review of modelling studies

Table 2. Summary of reviewed papers included in the review

\begin{tabular}{|c|c|c|}
\hline Paper $^{\#}$ & Cashore et al. 2020 & Gressman and Peck $2020^{5}$ \\
\hline Focus & $\begin{array}{l}\text { Assess the impact of opening Cornell's Ithaca campus and implementing } \\
\text { asymptomatic testing (screening), contact tracing, and quarantine measures, } \\
\text { compared to having full online/ virtual teaching to control COVID-19. }\end{array}$ & $\begin{array}{l}\text { Assess the impact of multiple interventions including testing, quarantining, } \\
\text { contact tracing, mask-wearing, and partial transition to online instruction on } \\
\text { COVID-19 in a university environment. }\end{array}$ \\
\hline Principal finding & $\begin{array}{l}\text { Combinations of contact tracing, testing and low initial prevalence } \\
\text { (supported by testing) can achieve meaningful control over outbreaks on } \\
\text { Cornell's Ithaca campus if screening is frequent enough ( } 5 \text { days) and if } \\
\text { quarantine capacity exceeds the peak requirement of } 700 \text { predicted by the } \\
\text { model. In this model a scenario of full online/ virtual teaching resulted in } \\
\text { more infections in the university community, due to a lack of screening. The } \\
\text { model is sensitive to several parameters and modest changes can result in } \\
\text { extremely high numbers of infections and hospitalisations. }\end{array}$ & $\begin{array}{l}\text { Campus outbreaks could be contained through a suite of interventions } \\
\text { including moving large classes online, mask wearing, large scale screening } \\
\text { (randomized testing), contact-tracing, and quarantining. If the size of the } \\
\text { quarantine population is to be kept manageable there must be high test } \\
\text { specificity. Moving the largest classes online is required to control the size } \\
\text { of outbreaks and the quarantine population. In this model (where typically } \\
\text { students have } 1 \text { residential contact) increased residential exposure impacts } \\
\text { the size of an outbreak considerable, however, controlling non-residential } \\
\text { social contacts may be more important. High quarantine rates even in } \\
\text { controlled outbreaks result in significant absenteeism from teaching. }\end{array}$ \\
\hline \multicolumn{3}{|r|}{ 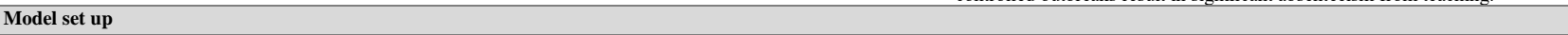 } \\
\hline Model type & $\begin{array}{l}\text { Initial prevalence - compartmental model; principal model - stochastic } \\
\text { transmission dynamic compartmental model }\end{array}$ & Full-scale stochastic agent-based model \\
\hline Structure & $\begin{array}{l}\text { Susceptible-Exposed-Infected-Recovered with additional stratification by } \\
\text { detectable and infectious individuals and symptomatic/asymptomatic states. }\end{array}$ & $\begin{array}{l}\text { Susceptible-Infected-Recovered with additional states for infected persons } \\
\text { (including the incubation period, whether or not they are symptomatic, and } \\
\text { how many days their infection has progressed) and quarantine. }\end{array}$ \\
\hline Mixing/ contact patterns & Random & $\begin{array}{l}\text { Academic contacts (five subcategories), broad social contacts and residential } \\
\text { contacts are based on individuals' common activities. }\end{array}$ \\
\hline Time horizon; time step & 112 day ( 16 weeks); daily & 100 days; daily \\
\hline \multicolumn{3}{|l|}{ Population } \\
\hline Total population & 34310 (Cornell Ithaca campus, New York, US) & 22500 (imaginary university) \\
\hline Population type & $\begin{array}{l}\text { Faculty (1684); Academic professionals (1114); Staff (7485); Students } \\
\text { (24027). Further divided into age groups. }\end{array}$ & 20000 students, 2500 instructors \\
\hline \multicolumn{3}{|l|}{ Interventions } \\
\hline Testing & $\begin{array}{l}\text { Testing on return to university: } 1 \text { test locally } 5 \text { days before students return } \\
\text { and } 1 \text { test (pooled testing) on arrival. Testing of asymptomatic individuals } \\
\text { every } 5 \text { days beginning just after move-in (which means } 1 / 5 \text { probability of } \\
\text { being tested on any day). Testing of symptomatic individuals. }\end{array}$ & $\begin{array}{l}\text { Random daily testing (screening) of } 100 \% \text { of the university community } \\
\text { population per month ( } 3 \% \text { daily). Testing of those identified through contact } \\
\text { tracing on the previous day. }\end{array}$ \\
\hline Contact tracing & $\begin{array}{l}\text { Yes, positive tests result in contact tracing with an assumed } 7 \text { contacts } \\
\text { meeting criteria for quarantine, all of whom are quarantined or isolated. }\end{array}$ & $\begin{array}{l}\text { Yes, positive tests and symptomatic persons result in contact tracing of } \\
\text { contacts from last two days with an assumed average of } 11 \text { traceable }(58 \%) \\
\text { and } 8 \text { nontraceable contacts per person per day when all classes are meeting } \\
\text { physically and no social distancing is being exercised. These contacts are } \\
\text { quarantined immediately and flagged for testing the next day. }\end{array}$ \\
\hline Quarantining/ isolation & $\begin{array}{l}\text { Yes, symptomatic persons and those testing positive are isolated and persons } \\
\text { contact traced are quarantined for } 14 \text { days. }\end{array}$ & Yes; symptomatic persons and those testing positive are isolated for 14 days. \\
\hline $\begin{array}{l}\text { Other non-pharmaceutical } \\
\text { interventions (NPIs) }\end{array}$ & Online teaching. & $\begin{array}{l}\text { Transmission probabilities are reduced by } 50 \% \text { to account for a variety of } \\
\text { NPIs (e.g. mask wearing, online teaching). }\end{array}$ \\
\hline $\begin{array}{l}\text { Summary of sensitivity analysis } \\
\text { considered }\end{array}$ & $\begin{array}{l}\text { Sensitivity analysis plots for each parameter; daily likelihood of } \\
\text { symptomatic individual self-reporting; initial prevalence of infection; } \\
\text { probability of transmission; contacts per day; contact trace delay; contact } \\
\text { tracing isolation per individual; probability that infected person is } \\
\text { asymptomatic; \% tested; false-negative rate; daily probability of infection } \\
\text { from outside interaction. Peak quarantine capacity needed in move-in } \\
\text { weekends under } 3 \text { scenarios (optimistic, nominal, pessimistic) }\end{array}$ & $\begin{array}{l}\text { Varying parameters: alternate choices of } \mathrm{R}_{0} \text {, values of false positive and false } \\
\text { negative rates, numbers of daily contacts. Interventions considered: standard } \\
\text { intervention consisted of quarantine and contact tracing, universal mask- } \\
\text { wearing, daily randomized testing of } 3 \% \text { of university community and } \\
\text { transitioning all classes with } 30 \text { or more students to online-only interaction, } \\
\text { other possible interventions were dividing large classes into many smaller } \\
\text { groups. }\end{array}$ \\
\hline \multicolumn{3}{|c|}{ 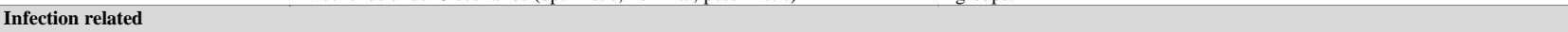 } \\
\hline Initial number infected & 31 & 0 \\
\hline $\begin{array}{l}\text { Importation of infection from } \\
\text { outside of University community }\end{array}$ & $\begin{array}{l}\text { Yes, each member of Cornell has a probability of being infected by a non- } \\
\text { Cornell person, dependent upon the prevalence locally. }\end{array}$ & $\begin{array}{l}\text { Yes, equivalent to } 25 \% \text { chance daily that one non-quarantined susceptible } \\
\text { individual becomes infected due to a non-university contact. }\end{array}$ \\
\hline Latent period/incubation period & $\begin{array}{l}\text { Latent period: } 2 \text { days } \\
\text { Incubation period: } 5 \text { days }\end{array}$ & Incubation period: 5.2 days \\
\hline $\begin{array}{l}\text { Duration pre-symptomatic but } \\
\text { infectious }\end{array}$ & 3 days & Not specified \\
\hline Total infectious period & 15 days & "Infectiousness serial interval" 5.8 days \\
\hline $\begin{array}{l}\text { Duration symptomatic until } \\
\text { present to health services }\end{array}$ & 4.545 days & 0 \\
\hline $\begin{array}{l}\text { Proportion of symptomatic who } \\
\text { present to health services }\end{array}$ & $100 \%$ & $100 \%$ \\
\hline Transmission rate & $\mathrm{R}_{0}=2.5$ & $\mathrm{R}_{0}=3.8$ \\
\hline Test sensitivity/ specificity & $\begin{array}{l}\text { Sensitivity } 90 \% \text { (false negative rate } 10.0 \% \text { ); specificity } 99.9 \% \text { (false positive } \\
\text { rate } 0.1 \% \text { ) }\end{array}$ & $\begin{array}{l}\text { Sensitivity } 97 \% \text { (false negative rate } 3.0 \% \text { ); specificity } 99.9 \% \text { (false positive } \\
\text { rate } 0.1 \% \text { ) }\end{array}$ \\
\hline Proportion/ number of tests & Screening $100 \%$ of university community every 5 days; 1400 tests daily & Screening $100 \%$ every month; 675 tests daily \\
\hline Proportion asymptomatic & $47.8 \%$, variable by age & $75 \%$ \\
\hline $\begin{array}{l}\text { Infectiousness of asymptomatic } \\
\text { vs symptomatic }\end{array}$ & Assumed equivalent & Asymptomatic assumed half as infectious as symptomatic \\
\hline Symptom severity & Varied by age & Not included \\
\hline COVID-related mortality & Not included & Not included \\
\hline Code available & $\begin{array}{l}\text { https://github.com/peter-i-frazier/group-testing } \\
\text { https://docs.google.com/spreadsheets/d/1E4hoMIvmHcq819KeVOTf7PyAt8 } \\
\text { 26UbBG4G2dnLTv42w/editgid=142118512 }\end{array}$ & https://www.github.com/gressman/covid university \\
\hline
\end{tabular}


medRxiv preprint doi: https://doi.org/10.1101/2020.09.07.20189688; this version posted September 9, 2020. The copyright holder for this preprint (which was not certified by peer review) is the author/funder, who has granted medRxiv a license to display the preprint in perpetuity.

It is made available under a CC-BY 4.0 International license.

COVID-19 transmission in a university setting: a rapid review of modelling studies

\section{Table 2. Summary of reviewed papers included in the review continued}

\begin{tabular}{|c|c|c|}
\hline Paper & Lopman et al. $2020^{3}$ & Martin et al. $2020^{6}$ \\
\hline Focus & $\begin{array}{l}\text { Assess the impact of testing, screening and isolation/quarantine on the } \\
\text { number of cases of COVID-19 in a university setting in the US (Emory } \\
\text { University, Atlanta, Georgia). }\end{array}$ & $\begin{array}{l}\text { Testing required to detect an outbreak at an early stage in a university } \\
\text { campus context in US. }\end{array}$ \\
\hline Principal finding & $\begin{array}{l}\text { Without any intervention the model estimates that hundreds of infections, } \\
\text { many hospitalisations and some deaths would occur (the authors recommend } \\
\text { the results are not interpreted quantitatively). In a scenario of social } \\
\text { distancing and mask wearing, testing symptomatic persons with isolation of } \\
\text { test positive cases, and tracing and quarantining } 75 \% \text { of their contacts is } \\
\text { effective at controlling transmission, though cases, hospitalisations and } \\
\text { potentially deaths may still occur. Testing the population regardless of } \\
\text { symptoms (screening) on a regular basis needs to occur at least monthly in } \\
\text { order to have much impact. }\end{array}$ & $\begin{array}{l}\text { When there are } 9 \text { or fewer detectable cases in the population monthly testing } \\
\text { of } 100 \% \text { of the campus community is required to detect an outbreak, unless } \\
\text { at least } 30 \% \text { of infected people develop symptoms that lead them to present } \\
\text { to a health service and be tested. }\end{array}$ \\
\hline \multicolumn{3}{|c|}{ 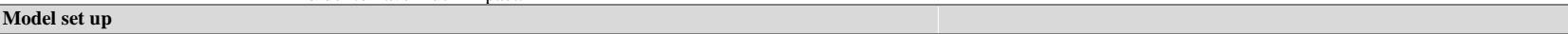 } \\
\hline Model type & Deterministic transmission dynamic compartmental model & Deterministic transmission dynamic compartmental model \\
\hline Structure & $\begin{array}{l}\text { Susceptible-Exposed-Infectious-Recovered with additional quarantine and } \\
\text { isolation compartments. }\end{array}$ & $\begin{array}{l}\text { Susceptible-Exposed-Infected-Recovered with additional stratification by } \\
\text { detectable and infectious individuals. }\end{array}$ \\
\hline Mixing/ contact patterns & $\begin{array}{l}\text { Mixing is homogenous within each of the three population types, but varies } \\
\text { between the groups. }\end{array}$ & Random \\
\hline Time horizon; time step & 116 days, daily & 70 days; daily \\
\hline \multicolumn{3}{|l|}{ Population } \\
\hline Total population & 30,266 (Emory University, Atlanta, Georgia, US) & 65000 (UC San Diego) \\
\hline Population type & $\begin{array}{l}\text { Students living on campus (4500), students living off campus (10500) and } \\
\text { staff/faculty (15266) }\end{array}$ & Not further specified \\
\hline \multicolumn{3}{|l|}{ Interventions } \\
\hline Testing & $\begin{array}{l}\text { Testing of the population regardless of symptoms (screening) at a given } \\
\text { frequency, from weekly to once a term. Testing of symptomatic individuals } \\
\text { who present for clinical care; includes a background rate of influenza-like } \\
\text { symptoms ( } 0.00333 \text { per day) for which persons will test negative. }\end{array}$ & $\begin{array}{l}\text { Testing of symptomatic individuals from the university community seeking } \\
\text { medical assistance with or without random daily testing (screening) of } 25 \% \text {, } \\
50 \%, 75 \% \text { or } 100 \% \text { of the university community population per month. }\end{array}$ \\
\hline Contact tracing & $\begin{array}{l}\text { Yes, positive tests result in contact tracing, with an assumed } 14 \text { contacts } \\
\text { identified by public health authorities and } 75 \% \text { successfully traced and } \\
\text { quarantined. }\end{array}$ & None \\
\hline Quarantining/ isolation & $\begin{array}{l}\text { Yes; those testing positive are isolated and persons contact traced are } \\
\text { quarantined for } 14 \text { days. }\end{array}$ & $\begin{array}{l}\text { Yes; symptomatic cases presenting to health services are diagnosed and } \\
\text { isolated. }\end{array}$ \\
\hline $\begin{array}{l}\text { Other non-pharmaceutical } \\
\text { interventions }\end{array}$ & Mask wearing and social distancing ( $70 \%$ efficacy) & 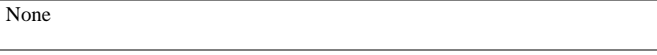 \\
\hline $\begin{array}{l}\text { Summary of sensitivity analysis } \\
\text { considered }\end{array}$ & $\begin{array}{l}\text { Probabilistic sensitivity analysis of parameters to investigate the importance } \\
\text { of specific parameters on model output and scenario analysis of varying: the } \\
\text { testing interval (the time between symptom onset and quarantine), screening } \\
\text { intervals, from weekly to once a semester, } \mathrm{R}_{0} \text {. }\end{array}$ & $\begin{array}{l}\text { Proportion of students who are asymptomatic or have mild symptoms that do } \\
\text { not seek medical assistance, transmission rate (R), and pre-existing } \\
\text { immunity. }\end{array}$ \\
\hline \multicolumn{3}{|c|}{ (2) } \\
\hline Initial number infected & 0 & 1 \\
\hline $\begin{array}{l}\text { Importation of infection from } \\
\text { outside of University community }\end{array}$ & $\begin{array}{l}\text { Yes, daily rate of introduction of virus onto campus from the community } \\
(0.00005) \text { based on local incidence of confirmed COVID- } 19 \text { cases and } \\
\text { assuming the actual incidence is ten-times greater than this. }\end{array}$ & None \\
\hline Latent period/incubation period & Latent period: 3 days & Latent period: 3 days \\
\hline $\begin{array}{l}\text { Duration pre-symptomatic but } \\
\text { infectious }\end{array}$ & 1 day & 2 days \\
\hline Total Infectious period & 7 days & $\begin{array}{l}14 \text { days (for those who become symptomatic this includes } 2 \text { days pre- } \\
\text { symptomatic, } 2 \text { days before presenting to health services and } 10 \text { days in } \\
\text { isolation) }\end{array}$ \\
\hline $\begin{array}{l}\text { Duration symptomatic until } \\
\text { present to health services }\end{array}$ & 2 days from onset of infectiousness to testing & 2 days \\
\hline $\begin{array}{l}\text { Proportion of symptomatic who } \\
\text { present to health services }\end{array}$ & $100 \%$ & $1 \%$ to $60 \%$ considered \\
\hline Transmission rate & $\begin{array}{l}\text { On campus student } R_{0}=3.5 \text {, off campus student } R_{0}=2.5 \text {, staff to staff or } \\
\text { student } R_{0}=\text { of } 0.5\end{array}$ & $\mathrm{R}_{0}=2$ to 3 considered \\
\hline Test sensitivity/ specificity & $\begin{array}{l}\text { Sensitivity varies by day of infectiousness: } 75 \%, 80 \%, 75 \% \text { for days } 2,4 \text { and } \\
7 \text { of infectiousness respectively }\end{array}$ & Sensitivity $85 \%$ \\
\hline Proportion/ number of tests & $\begin{array}{l}\text { Screening } 100 \% \text { with scenarios of weekly to once a semester. } \\
\text { For testing with 4-day delay to test } n=14038 \text { ( } 46 \% \text { of population) }\end{array}$ & Screening $100 \%$ every month \\
\hline Proportion asymptomatic & Students $65 \%$, staff and faculty $49 \%$ & $1 \%$ to $30 \%$ considered \\
\hline $\begin{array}{l}\text { Infectiousness of asymptomatic } \\
\text { vs symptomatic }\end{array}$ & Assumed equivalent & Assumed equivalent \\
\hline Symptom severity & Staff have a higher risk of severe illness $(0.055)$ than students $(0.0224)$. & Not included \\
\hline COVID-related mortality & Proportion fatal: students 0.0006, staff 0.0052 & Not included \\
\hline Code available & Shiny app available from https://epimodel.shinyapps.io/covid-university/ & No \\
\hline
\end{tabular}


medRxiv preprint doi: https://doi.org/10.1101/2020.09.07.20189688; this version posted September 9, 2020. The copyright holder for this preprint (which was not certified by peer review) is the author/funder, who has granted medRxiv a license to display the preprint in

perpetuity.
It is made available under a CC-BY 4.0 International license .

COVID-19 transmission in a university setting: a rapid review of modelling studies

Table 2. Summary of reviewed papers included in the review continued

\begin{tabular}{|c|c|}
\hline Paper & Virtual Forum for Knowledge Exchange (V-KEMS) ${ }^{7}$ \\
\hline Focus & $\begin{array}{l}\text { Impact of disease transmission amongst freshers on campus when there is a } \\
\text { social bubbling strategy enforced.\$ }\end{array}$ \\
\hline Principal finding & $\begin{array}{l}\text { The benefit of social bubbles diminish as the chance of individuals within a } \\
\text { bubble being infected (due to background infection rate) increases. Smaller } \\
\text { bubble sizes withstand higher rates of community infection. A further } \\
\text { (tentative) finding is that low-between bubble interaction or high rates of } \\
\text { testing are required to avoid large outbreaks. }\end{array}$ \\
\hline \multicolumn{2}{|r|}{ o } \\
\hline Model type & Stochastic transmission dynamic compartmental model \\
\hline Structure & $\begin{array}{l}\text { Two models are presented with comparable parameters (1) Susceptible- } \\
\text { Infected-Recovered model used to estimate social bubble sizes on size of } \\
\text { epidemics (2) timestep Susceptible-Exposed-Infected-Recovered to evaluate } \\
\text { the effect of testing }\end{array}$ \\
\hline Mixing/ contact patterns & Random \\
\hline Time horizon; time step & 50 days; daily \\
\hline \multicolumn{2}{|l|}{ Population } \\
\hline Total population & 1536 \\
\hline Population type & Hypothetical on-campus freshers assorted into bubbles of size 12,24 or 48 \\
\hline \multicolumn{2}{|r|}{ 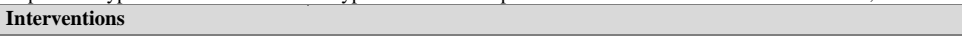 } \\
\hline Testing & $\begin{array}{l}\text { In the second model, testing is parameterised as rate of infection detection } \\
\text { per day }\end{array}$ \\
\hline Contact tracing & None \\
\hline Quarantining/isolation & $\begin{array}{l}\text { Immediate quarantine upon detection and isolation is for longer than a } \\
\text { 'reasonable infectious period' }\end{array}$ \\
\hline $\begin{array}{l}\text { Other non-pharmaceutical } \\
\text { interventions }\end{array}$ & Social bubbling \\
\hline $\begin{array}{l}\text { Summary of sensitivity analysis } \\
\text { considered }\end{array}$ & $\begin{array}{l}\text { Simulations were repeated over different sets of parameters, varying the } \\
\text { bubble sizes and the number of outside-bubble contacts }\end{array}$ \\
\hline \multicolumn{2}{|l|}{ Infection related } \\
\hline Initial number infected & Not stated \\
\hline $\begin{array}{l}\text { Importation of infection from } \\
\text { outside of University community }\end{array}$ & None \\
\hline Latent period/ incubation period & Not stated \\
\hline $\begin{array}{l}\text { Duration pre-symptomatic but } \\
\text { infectious }\end{array}$ & Not stated \\
\hline Infectious period & Not stated \\
\hline $\begin{array}{l}\text { Duration symptomatic until } \\
\text { present to health services }\end{array}$ & Not stated \\
\hline $\begin{array}{l}\text { Proportion of symptomatic who } \\
\text { present to health services }\end{array}$ & Not included \\
\hline Transmission rate & Not stated \\
\hline Test sensitivity & Specificity $100 \%$ \\
\hline Proportion/ number of tests & Variable \\
\hline Proportion asymptomatic & Not stated \\
\hline $\begin{array}{l}\text { Infectiousness of asymptomatic } \\
\text { vs symptomatic }\end{array}$ & Assumed equivalent \\
\hline Symptom severity & Not included \\
\hline COVID-related mortality & Not included \\
\hline Code available & No \\
\hline
\end{tabular}


medRxiv preprint doi: https://doi.org/10.1101/2020.09.07.20189688; this version posted September 9, 2020. The copyright holder for this

preprint (which was not certified by peer review) is the author/funder, who has granted medRxiv a license to display the preprint in

It is made available under a CC-BY 4.0 International license.

COVID-19 transmission in a university setting: a rapid review of modelling studies

\section{Results}

\section{Summary of study selection}

An initial search of PubMed including (COVID or coronavirus or SARS) did not return any hits, so a wider search was included to identify potentially relevant peer-reviewed papers considering other infectious disease models of campus transmission. The search of PubMed yielded 127 hits of which 20 were shortlisted for full text screening and 0 were included in the review. The Web of Science search yielded 7 hits, of which 2 were shortlisted for full text screening and 0 included in the review. The search of bioRxiv and medRxiv returned 205 records; after screening of titles 22 were selected for full text assessment and 3 papers were included in the review. Excluded papers did not report COVID-19 transmission in a university setting. Request to experts (via social media) resulted in 6 papers of which 4 were included in the review. In total, after removing duplicates, we identified 5 papers describing mathematical models in a university context, 4 with a US focus and 1 from UK. A summary of the papers included in the review is presented in Table 2.

\section{How SARS-CoV-2 infection is modelled in a university setting}

All of the models included in the review are transmission dynamic, that is, the amount of SARS-CoV2 transmission is related to the number of infected people over time and responds to changes in infection risk as a result of interventions - this is critical to assess the direct and indirect impact of potential control strategies. Most were compartmental models, which divides up the population into distinct groups; only one ${ }^{5}$ was agent-based which models individuals within a population. All models used a Susceptible-Exposed (latent)-Infectious-Recovered structure to capture the progression of infection in the population though the time period. Two models allowed for some individuals to be immune to COVID-19 at the start of the academic term ${ }^{56}$, though only Gressman and Peck ${ }^{5}$ included this in their base case model. The length of time for each infection state (for example, how long people were infectious for) and the assumptions about the transmissibility of the infection varied between models; only two models explicitly included pre-symptomatic transmission. Fundamentally, infection is spread between people through 'effective' contacts, so how people come into contact with each other is important. The way this is done across the five included papers is quite different, ranging from random mixing, to random mixing within a small number of different groups, to highly specified mixing patterns in the agent based model based on individuals' shared activities. Altering the assumptions about these parameters makes a considerable difference to the estimated potential outbreak in a university setting and the impact of any control measures. All the models assume that once infected persons have recovered, they are immune to re-infection. Only three models consider importation of infection from the wider community into the university population; none of the models included in the review considered the exporting of infection from the university community into the wider population. Most models start with very few initial cases, in some instances zero cases with the university epidemic starting due to importation from the local community. For one paper the low starting number is due to testing of students prior to and on return to university, with isolation if positive (see below) ${ }^{4}$. Two papers present predictions for SARS-CoV-2 infections in the autumn term without any control measures ${ }^{35}$; one estimates $89.4 \%$ of the campus population would be infected by the end of the semester ${ }^{5}$ and the other predicted $19.5 \%$ of the university community would be symptomatic (many more would be infected and be asymptomatic). When explicitly considered some of these infections result in fatalities. Infection numbers increased rapidly in the absence of intervention ${ }^{6}$.

\section{Interventions considered in models}

\section{Testing}

Testing interventions included: testing students before they travelled to campus; testing students on return to campus; testing symptomatic persons ${ }^{3}$; and testing asymptomatic individuals ${ }^{3}$ (here we refer to this regular testing as screening when done on mass, others term this testing, screening, or surveillance). Only one paper considered testing students before they travelled to campus and the 
medRxiv preprint doi: https://doi.org/10.1101/2020.09.07.20189688; this version posted September 9, 2020. The copyright holder for this preprint (which was not certified by peer review) is the author/funder, who has granted medRxiv a license to display the preprint in

It is made available under a CC-BY 4.0 International license.

COVID-19 transmission in a university setting: a rapid review of modelling studies

same paper also considered testing individuals upon their return to the university setting (pooled testing on arrival $)^{4}$. Lopman et al. explicitly state they did not include return to campus testing because they felt it would have limited effect given in their model the student prevalence is assumed to be the same as the general population ${ }^{3}$. Several papers ${ }^{3467}$ include near-immediate testing of symptomatic individuals; Gressman and Peck considered isolation but not testing of symptomatic persons ${ }^{5}$. Several symptoms associated with COVID-19 are generic to other infections. Particularly as we approach winter many persons may have what appear to be COVID-19 symptoms but not have SARS-CoV-2 - this has implications for the number of tests that may be needed and isolation/quarantine policies. Only one model included a background rate of influenza-like illness, with persons subsequently testing negative for SARS-CoV-2 ${ }^{3}$. All papers considered screening with the rate of testing asymptomatic persons per day varying between and within papers. Martin et al. considered varying random daily screening rates so that $25 \%, 50 \%, 75 \%$, or $100 \%$ of the university community population would be screened per month. Cashore et al. ${ }^{4}$ investigated testing the entire university community on average once every 5 days, Gressman and Peck ${ }^{5}$ considered this every month, whilst Lopman et al. ${ }^{3}$ also looked at varying these screening rates from weekly to once a term. The V-KEMS paper looked at testing parameterised as a rate of infection detection per day (from 0 to $1)^{7}$. Gressman and Peck ${ }^{5}$ also included testing of those identified through contact tracing. The sensitivity and specificity of tests is not $100 \%$. This has implications for the number of true positive cases not identified who can then go on to infect others and also how many individuals you may needlessly isolate and quarantine, discussed further below. Test sensitivity varied across the models from $75 \%^{3}$ to $97 \%^{5}$; only one paper considered variability in testing sensitivity over the course of an infection ${ }^{3}$.

\section{Contact tracing}

Contact tracing was included in three of the models ${ }^{3-5}$ and the number of traceable contacts modelled per case varied. Lopman et al. assumed that on average 14 contacts of individuals testing positive would be identified by public health authorities and 75\% (10.5) of these would be successfully traced and quarantined. In the Gressman and Peck paper each individual testing positive or developing symptoms had their contacts from the last two days traced on the next day with an assumed 19 contacts, of which $58 \%$ (11) would be traceable; this is the only model that includes testing for quarantined persons. Cashore et al. included seven contacts meeting the criteria for quarantine for each person testing positive, and investigated via sensitivity analyses the effect of different delay periods for contact tracing and lengths of isolation periods for traced individuals.

\section{Isolation and quarantining}

All papers include isolation of symptomatic persons, though some include a delay between symptom onset and testing with isolation only happening once the person has tested positive. All of the reviewed papers except for that by Martin et al. included quarantining of traced contacts in their models, with most using a 14 day quarantine period, whilst V-KEMS have quarantine operating for 'longer than a reasonable infectious period' 7 . Where included, models assume quarantining reduces contacts to zero, meaning quarantined persons cannot infect others, and if uninfected, are protected from further exposure. The only paper to explicitly include false positives from testing (specificity) is Gressman and Peck, which is important for considering how many people may be subject to quarantine despite not being in contact with a positive case. None of the papers considered quarantining of individuals traveling from high-risk COVID-19 areas as a stand-alone intervention.

\section{Additional non-pharmaceutical interventions}

All but one paper considered some form of other non-pharmaceutical intervention. These included reducing contacts through moving face-to-face teaching online ${ }^{45}$, social distancing ${ }^{3}$, and reducing contacts through the use of social bubbles ${ }^{7}$, or reducing transmission in face-to-face interactions by wearing face coverings. ${ }^{35}$ In both Gressman and Peck and Lopman et al. these are modelled by having 
medRxiv preprint doi: https://doi.org/10.1101/2020.09.07.20189688; this version posted September 9, 2020. The copyright holder for this preprint (which was not certified by peer review) is the author/funder, who has granted medRxiv a license to display the preprint in

It is made available under a CC-BY 4.0 International license.

COVID-19 transmission in a university setting: a rapid review of modelling studies

a term that generally reduces infection transmission by a specified amount, so could encompass a variety of non-pharmaceutical interventions (for example, increased hand hygiene).

\section{Synthesis of key model findings}

In the absence of control interventions, all models suggest a significant potential for transmission of COVID-19 in universities with rapid growth in case numbers shortly after the start of the academic year once the students return to campus. Analysis of where in the country, and which countries, students will be coming from may indicate how many infected persons a university might expect on the first day of term. Most models considered only a very low number of infected students at the start of term so infection spread could be quicker than presented in these papers, although this is highly dependent upon the prevalence rates of the home locations of incoming students at the time of departure. The assumptions about the rate of transmission in this context are critical for estimating how large an outbreak any institution might experience and how effective any given control measure may be. Most models considered US institutions of varying sizes, which may only be partially relevant to institutions in other countries, and in most cases there were relatively simple assumptions about how people mix with each other. Lopman et al. state that moving more students to off-campus housing may make little difference to their conclusions because on-campus transmission is only moderately higher than off-campus ${ }^{3}$. However, this may not be the case in all institutions and modifying how students are placed in first year accommodation may have a large impact in some university settings.

Early outbreak detection is critical to controlling the spread of infection. Given the high proportion of asymptomatic cases likely to be observed in the student population, screening will probably be needed to identify increasing case numbers before there is a very widespread problem. Martin et al. found when there are nine or fewer detectable cases in the population, monthly testing of $100 \%$ of the campus community is required to detect an outbreak, unless at least $30 \%$ of infected people develop symptoms that lead them to present to a health service and be tested ${ }^{6}$. Models suggest meaningful control over outbreaks could be achieved through testing of symptomatic people and screening of the asymptomatic university community along with isolation of those who are infected (regardless of symptoms), contact tracing, and quarantining of those traced. However, strategies relying on this approach alone need to be very aggressive, with high levels of ascertainment in both testing and tracing to be effective. The assumed success rate of contact tracing in the models that considered this $(58 \%, 75 \%$ and $100 \%)$ was generally higher than currently being achieved with the track and trace system in the UK (an average of $73 \%$ for the 3 weeks reported to 12 August $^{8}$ ) and compliance with quarantine was $100 \%$, which may well be unrealistic.

Cashore et al. included testing of students before travel to university, testing on arrival and testing of the university community every five days ${ }^{4}$. This would be logistically and financially challenging for many institutions. Models indicate that testing for symptomatic persons needs to be timely (less than a week between symptoms and positive test) and accompanied by effective isolation of the affected individual and subsequent contact tracing and quarantining of contacts in order to be really effective; much of the reduction in case numbers through more timely testing was due to the greater number of contacts reached in these scenarios ${ }^{3}$. The number of students in isolation and quarantine at any one time was considerable in some models, for example, Cashore et al. suggest planning for a peak quarantine capacity in excess of 700 in a population of $34310^{4}$ (cumulative estimates over the term were not reported). We consider it quite likely that there will be more delays in the system than modelled in many of the papers included in this review, that is, symptomatic people may not get tested and isolate themselves immediately, and contact tracing with quarantine may not be as successful, so control may be more challenging than presented without additional mitigation. Combinations of interventions are likely to be required to effectively control infection ${ }^{5}$ and several options are available (see appendix). When evaluated, the number of cases was sensitive to the frequency of screening ${ }^{34}$ even with other mitigation measures in place; screening was required at least 
medRxiv preprint doi: https://doi.org/10.1101/2020.09.07.20189688; this version posted September 9, 2020. The copyright holder for this preprint (which was not certified by peer review) is the author/funder, who has granted medRxiv a license to display the preprint in

It is made available under a CC-BY 4.0 International license.

COVID-19 transmission in a university setting: a rapid review of modelling studies

monthly for the whole university community to make a discernible impact. In models where other non-pharmaceutical interventions were not considered, screening was essential for COVID-19 control and findings were sensitive to the frequency of screening ${ }^{4}$. Screening was relatively less important when a package of interventions including partial online teaching to reduce contacts, use of facecoverings, and social/ physical distancing was used ${ }^{35}$. Gressman and Peck found moving classes with $30+$ students online was a big driver in keeping infections low (moving the largest classes with 100+ students was particularly critical) and that face-masks were also moderately important (universal mask-wearing was assumed to reduce transmission by 50\%). However, this model assumed an average of only one residential contact per student, and as residential and broad social contacts (dining halls/ restaurants, social events etc) were increased, these became more important in driving case numbers ${ }^{5}$. Limiting face-to-face contacts reduces infection spread. If students are placed into bubbles where only a small number of individuals mix with each other, low levels of interaction between bubbles are required to avoid large outbreaks and bubbles are of less benefit with increasing chance of infection from the wider community ${ }^{7}$ and may not be acceptable to students. Additionally, Gressman and Peck conclude large classes need to be held online to reduce the risk of a significant outbreak and it is not enough to break large face-to-face classes into smaller ones. ${ }^{5}$ Even small numbers of contacts between students in large group settings (dining halls/parties) may be sufficient to sustain an outbreak, even with other interventions in place $^{5}$.

\section{Discussion}

All models suggest a significant potential for transmission of COVID-19 in universities. Early identification of cases is critical to inform effective infection control. Smaller outbreaks are easier to control, thus symptom monitoring and testing will be an important feature of outbreak control and management. Seasonal effects may be important; SARS-CoV-2 may be more transmissible in winter and an increase in background influenza-like illness may lead to increased testing and self-isolation, increasing the burden on university support systems. Modelling findings suggest that regular testing strategies (including testing asymptomatic individuals), isolation of infected individuals and contact tracing, together with use of face coverings and social distancing measures to reduce class sizes and face-to-face teaching could be effective in controlling transmission of COVID-19 in universities. One study found moving teaching online and wearing masks ${ }^{5}$ was more important than screening (monthly) to mitigate cases, however, the screening may be more valuable with higher frequencies of testing. In models much of the importance of testing was due to the impact of effective contact tracing and isolation/quarantining reducing onward transmission, but high numbers of contacts must be reached to be effective. Specificity of testing is important because even a low false positive rate could lead to a considerable number of uninfected students being quarantined ${ }^{5}$, especially when contact tracing is taken into consideration. A policy of reconfirming positives could avoid unnecessary quarantining, which could be important for managing the student population's adherence to any guidance. Most of the studies identified that even with strong control measures in place, isolation of symptomatic cases and quarantine of contacts for 14 days may have a large impact on attendance of students (and staff) requiring online options for quarantining students even where inperson classes are taking place. Multiple interventions are likely to be needed to control infection spread within this setting and efforts to reduce transmission may be limited given the connectivity of students, staff, and the wider community, the varying capacity of institutions to employ such aggressive mitigation interventions, and likely varying compliance with any interventions imposed.

To our knowledge this is the first review of modelling studies considering COVID-19 infection in a university setting. The results are timely given universities are currently making decisions about if and how to re-open for the autumn term - there is no universal guidance for universities about how to do this and indeed university responses may need to be tailored to the institution given the variations in geography (campus or city based, in areas of high or low community infection) and student body. 
medRxiv preprint doi: https://doi.org/10.1101/2020.09.07.20189688; this version posted September 9, 2020. The copyright holder for this preprint (which was not certified by peer review) is the author/funder, who has granted medRxiv a license to display the preprint in perpetuity.

It is made available under a CC-BY 4.0 International license.

COVID-19 transmission in a university setting: a rapid review of modelling studies

The general messages here about the importance of quarantining and the need for multiple interventions for COVID-19 control in a university setting are consistent with work considering all settings ${ }^{9}$. We only found pre-prints relevant for inclusion, thus the papers here have not been through the critique of peer-review, which often results in authors being asked to provide additional information required for accurate interpretation of results or to amend analysis approaches. This presents a challenge for the review, however, bringing together the available evidence is critical now to help understand how universities may be affected by COVID-19 when they re-open in the next few months. We also only considered papers in English and from a select number of potential sources, therefore it is possible we have missed some models that could be relevant. Most papers had a US focus; the size and set-up of universities in other countries may be quite different to these institutions, influencing contact patterns and thus the spread of infection so policy makers should be mindful that mitigation strategies may perform differently in different settings. This rapid review has focused on mathematical models of SARS-CoV-2 infection and disease in a university setting, however, we are aware of other work that may be useful for informing policy decisions around how best to manage COVID-19 in this sector. Research assessing real contact patterns between college students in different countries has shown differences in the number and network of close proximity interactions, and that this influenced the spread of influenza ${ }^{10}$, thus considering local contact patterns is important for understanding potential risk and mitigation strategies. An increased risk of infectious diseases has been observed with mass gatherings ${ }^{11}$ and epidemiological studies have shown the capacity for infectious diseases to spread rapidly in a university context. For example, in a study of 2507 students in their first year at University of Nottingham in 1997, carriage of meningococci (a bacterium transmitted through droplets of respiratory and throat secretions from carriers) increased rapidly over the first week of term from $6.9 \%$ on day 1 to $23.1 \%$ on day $4^{12}$. For students living in catered halls the average carriage rate increased from $13.9 \%$ during the first week of term in October, to $31.0 \%$ in November and $34.2 \%$ in December ${ }^{12}$. Mathematical models for influenza have captured the spread of this illness in students and outbreaks with high attack rates have been observed in universities ${ }^{13}$. Indeed 'Freshers (freshman) flu' - caused by a number of infections (not necessarily influenza) - is well-known for causing illness amongst students during the first few weeks at university.

Students come to university from across the country and world - given the rapidly changing epidemiological situation is it unclear how many infected students each institution may have at the start of term. Individuals are at risk of contracting COVID-19 in the community, so even institutions considering wholly online teaching will still need to consider how best to support students and staff who may become unwell. There are also challenges when students return home, both within and at the end of term, in terms of potentially spreading infection. International students are likely to face particular challenges with uncertainties around travel and their ability to return home at the end of term. Interventions to minimise contacts for a period at the start and end of term, including quarantining all students, could be effective at avoiding outbreaks. While the university campus environment can be controlled to some extent, the students live within a wider local community accessing public transport, shops, bars, and restaurants, and many have part-time jobs, thus the relationship between the university community and the general population is important for driving infection. Universities are considering intervention measures that go beyond government advice to augment national outbreak control systems to meet the particular challenges faced in this sector. All universities should be working on strategies that reduce face-to-face interactions in the university community and mitigate potential SARS-CoV-2 transmission where interactions must take place, through use of physical distancing, hand sanitising and with use of face coverings. Structural changes such as moving teaching online and influencing the dynamics of students mixing, particularly those living in first year university accommodation, are difficult for people to avoid. Testing was found to be important in some models to limit outbreaks, and multiple interventions, including regular university population testing has been recommended by Independent SAGE ${ }^{14}$. However, not all universities have access to in-house testing and even where they do this may be logistically 
medRxiv preprint doi: https://doi.org/10.1101/2020.09.07.20189688; this version posted September 9, 2020. The copyright holder for this preprint (which was not certified by peer review) is the author/funder, who has granted medRxiv a license to display the preprint in

It is made available under a CC-BY 4.0 International license.

COVID-19 transmission in a university setting: a rapid review of modelling studies

challenging and expensive if deployed widely and regularly. Any testing provision will require close liaison with existing national systems (Local Authority and Public Health England). For those with capacity, batch or pooled testing may facilitate testing, but this raises issues about the sensitivity and specificity of such protocols. Individuals must also be willing to undergo testing - differential compliance between groups of lower and higher risk for transmission could have important implications for how effective testing may $b^{6}$. Asymptomatic screening is assumed to happen at regular intervals across term when included in the models ${ }^{4}$, however, testing frequency may need to be adjusted in response to changing incidence/prevalence in order to be most effective in informing control strategies ${ }^{4}$. The national contact tracing system has been criticised for not being adequate, prompting some areas to set up their own ${ }^{15}$ - universities may need to consider whether additional tracing support may be helpful for their context. Antibody responses may not be long lasting ${ }^{16} 17$ (although other elements of the immune system may be longer lasting, though this is unknown) - so models assuming long term immunity may be over optimistic. Many potential interventions strategies are being considered and even if theoretically effective for controlling COVID-19 may not be feasible on the ground, thus clear information should be given to students, staff, and the wider community about what is realistic and the implications of this. There may be important negative consequences of some COVID-19 mitigation strategies in terms of the wellbeing of individuals

The situation with COVID-19 is rapidly evolving and there are a number of unanswered questions around the epidemiology. The infectiousness of asymptomatic persons is critical; it is believed to be lower than that of symptomatic individuals but largely unknown. This is particularly important in a university setting where it is currently assumed the vast majority of students are likely to be asymptomatic. Universities have a duty of care to students and to staff and the models identified in this review primarily consider the typical student and staff population. We know individuals from particular ethnic backgrounds and with underlying health conditions are at increased risk of poor outcomes from COVID-19 and this should be considered in university planning. Modelling and epidemiological evidence from the UK suggests that staff, such as catering and cleaning personnel, may be at particular risk. Other groups such as library or student administrative staff also have high rates of contact with students and may therefore be at elevated risk compared to other staff. The models have considered accommodation and teaching facilities, but not specifically risks of transmission in other settings such as public transport (including student buses), the use of other facilities such as sports centres or canteens, or social settings such as clubs and societies.

Additionally, mathematical models could usefully focus on the incremental benefit of each additional intervention, particularly screening, to aid decision making.

Most of the models have considered campus universities in the US. In the UK there may be additional considerations. Differences for campus or city integrated universities in terms of mixing with general population are important for importation of infection to the university community, but also spill over of any university outbreaks into the community. However, limited work has been done in this area to date. There is much uncertainty in the model parameters and the structure of the models, particularly related to how people mix with each other. Student behaviour and mental health under quarantine is important, particularly as many students have small living quarters. Quarantining for students new to university may find isolation particularly lonely and significantly adversely affect mental health - if parents choose to pick up their students for quarantining at home this may drive an increase in community transmission leading to a worse outcome nationally. Additional risk to the broader population is due to education and accommodation breaks during reading weeks, Christmas and Easter holidays. Requiring students to remain at university during those times is unlikely, and should a substantial number of cases be present in the student population, a large-scale return to home is likely to disperse the infection across the country.

In summary, the modelling COVID-19 studies in a university setting that have been reported to date point to the essential requirement for mitigation measures tailored to the student context. Enhanced 
medRxiv preprint doi: https://doi.org/10.1101/2020.09.07.20189688; this version posted September 9, 2020. The copyright holder for this

preprint (which was not certified by peer review) is the author/funder, who has granted medRxiv a license to display the preprint in

It is made available under a CC-BY 4.0 International license.

COVID-19 transmission in a university setting: a rapid review of modelling studies

testing, including rapid testing of symptomatic individuals as well as screening of asymptomatic individuals should be given close consideration. Rapid contact tracing, effective student support for adherence to isolation and quarantine alongside a suite of other established mitigation measures all have a place in effective outbreak control. The situation is dynamic and although the large scale migration of over 2 million students to arrive at or return to their university locations in the Autumn is the immediate focus of attention, universities will need to closely monitor the developing situation and be able to adapt and rapidly respond to the likely occurrence of future outbreaks.

\section{Acknowledgements}

HC, KT and EBP acknowledge support from the NIHR Health Protection Research Unit in Behavioural Science and Evaluation at University of Bristol. The Health Protection Research Unit (HPRU) in Behavioural Science and Evaluation at University of Bristol is part of the National Institute for Health Research (NIHR) and a partnership between University of Bristol and Public Health England (PHE), in collaboration with the MRC Biostatistics Unit at University of Cambridge and University of the West of England. We are a multidisciplinary team undertaking applied research on the development and evaluation of interventions to protect the public's health. Our aim is to support PHE in delivering its objectives and functions. Follow us on Twitter: @ HPRU_BSE

RDB acknowledges support from the Elizabeth Blackwell Institute for Health Research, University of Bristol.

LD is supported by Medical Research Council (MRC) (MC/PC/19067) The Alan Turing Institute EPSRC EP/N510129/1.

\section{Funding statement}

There was no project specific funding for this work; the funders of the co-authors did not have a role in the conception, design or writing of the manuscript.

\section{Author contributions statement}

EBP conceived the study, HC and KT designed and ran the searches, and reviewed the papers for inclusion. HC, RDB, AT, EN, GH extracted the data from relevant papers. All authors wrote and critically reviewed the manuscript.

\section{Competing interests}

The authors declare no competing interests. 
medRxiv preprint doi: https://doi.org/10.1101/2020.09.07.20189688; this version posted September 9, 2020. The copyright holder for this preprint (which was not certified by peer review) is the author/funder, who has granted medRxiv a license to display the preprint in perpetuity.

It is made available under a CC-BY 4.0 International license.

COVID-19 transmission in a university setting: a rapid review of modelling studies

\section{Appendix}

Table A1. Potential interventions - highlighted rows show interventions considered in some form in mathematical models included in this review.

\begin{tabular}{|c|c|}
\hline Intervention & Comments \\
\hline $\begin{array}{l}\text { Smaller class sizes for face- } \\
\text { to-face teaching }\end{array}$ & Allow only small classes to meet in person \\
\hline $\begin{array}{l}\text { Virtual instruction for some } \\
\text { students/classes }\end{array}$ & This could include transitioning large classes to online only. \\
\hline $\begin{array}{l}\text { Virtual instruction for all } \\
\text { students }\end{array}$ & $\begin{array}{l}\text { Students and staff will still be at risk of infection from the community; } \\
\text { screening would only be possible for a reduced number of students and } \\
\text { faculty/staff. }\end{array}$ \\
\hline Face coverings/masks & $\begin{array}{l}\text { Using masks has implications for teaching and learning - face shields for } \\
\text { lecturers could facilitate lip-reading/clarity. }\end{array}$ \\
\hline Social distancing & $\begin{array}{l}\text { This can include physical distancing and within University buildings } \\
\text { encourage 1-way flow and distancing. Lower building occupancy on-site } \\
\text { reduces pressure on shared facilities such as canteens/toilets etc. }\end{array}$ \\
\hline $\begin{array}{l}\text { Bubbles for courses or } \\
\text { accommodation }\end{array}$ & $\begin{array}{l}\text { Aim to minimise contact between groups of students. May increase } \\
\text { contact time for tutors if teaching smaller groups multiple times. Difficult } \\
\text { to enforce in accomodation. University accommodation is varied, even } \\
\text { within an institution and can includes halls arranged in flats, with shared } \\
\text { kitchen, but en-suite bathrooms to halls with larger corridors of rooms, } \\
\text { shared bathrooms and large dining halls. }\end{array}$ \\
\hline Cleaning of facilities & Regular cleaning of facilities. \\
\hline $\begin{array}{l}\text { Hand washing and alcohol } \\
\text { gels }\end{array}$ & Encourage regular handwashing and provide alcohol gels \\
\hline Communications & $\begin{array}{l}\text { Information to students about symptoms (symptom survey), numbers of } \\
\text { cases in students, in wider community. Positive messaging about mask } \\
\text { use/ hand hygiene. }\end{array}$ \\
\hline $\begin{array}{l}\text { Testing prior to arrival to } \\
\text { university }\end{array}$ & $\begin{array}{l}\text { Reduces the number of infected persons travelling at the start of term if } \\
\text { combined with effective isolation policies. }\end{array}$ \\
\hline $\begin{array}{l}\text { Testing on arrival to } \\
\text { university }\end{array}$ & Reduces the number infected at the start of term. \\
\hline Testing if symptomatic & $\begin{array}{l}\text { Clear advice and signposting - how to get a test, who to tell, what to do } \\
\text { (isolation/quarantine). Contact tracing (including bubbles) and other close } \\
\text { contacts. Needs to be rapid and linked with local public health. }\end{array}$ \\
\hline $\begin{array}{l}\text { Testing of university } \\
\text { community without } \\
\text { symptoms (screening) }\end{array}$ & $\begin{array}{l}\text { Various strategies are possible considering the proportion and frequency of } \\
\text { testing and whether testing is random across the population or focused on } \\
\text { potentially high risk groups. }\end{array}$ \\
\hline $\begin{array}{l}\text { Regular pooled testing of } \\
\text { "bubbles" }\end{array}$ & $\begin{array}{l}\text { Bubbles based on course or accommodation would allow rapid } \\
\text { communication with the most likely close contacts. }\end{array}$ \\
\hline Contact tracing & $\begin{array}{l}\text { Initiated when individual self-reports or is test positive, leading to } \\
\text { quarantine for contacts }\end{array}$ \\
\hline $\begin{array}{l}\text { Short term request to } \\
\text { minimise contacts }\end{array}$ & $\begin{array}{l}\text { Minimising or eliminating contacts until test results are back and/or } \\
\text { request to minimise contacts before returning to university and not } \\
\text { travelling when symptomatic. }\end{array}$ \\
\hline $\begin{array}{l}\text { Recognition of (mild) } \\
\text { symptoms, seeking testing } \\
\text { and self-isolation }\end{array}$ & $\begin{array}{l}\text { Education and awareness materials about recognising COVID-19 } \\
\text { symptoms and information on getting tested promptly can help with this; } \\
\text { completion of symptom surveys, links with Public Health England, NHS, } \\
\text { local authorities and university. }\end{array}$ \\
\hline
\end{tabular}


medRxiv preprint doi: https://doi.org/10.1101/2020.09.07.20189688; this version posted September 9, 2020. The copyright holder for this preprint (which was not certified by peer review) is the author/funder, who has granted medRxiv a license to display the preprint in perpetuity.

It is made available under a CC-BY 4.0 International license.

COVID-19 transmission in a university setting: a rapid review of modelling studies

\section{References}

1. Office for National Statistics. Coronavirus (COVID-19) Infection Survey: characteristics of people testing positive for COVID-19 in England, August 2020. 2020. [updated 18 August 2020]. Available from:

https://www.ons.gov.uk/peoplepopulationandcommunity/healthandsocialcare/conditionsanddiseases/a rticles/coronaviruscovid19infectionsinthecommunityinengland/characteristicsofpeopletestingpositivef orcovid19inenglandaugust2020\#characteristics-of-individuals-testing-positive-for-covid-19antibodies [accessed 24 August 2020].

2. Liberati, A, Altman, DG, Tetzlaff, J, et al. The PRISMA statement for reporting systematic reviews and meta-analyses of studies that evaluate healthcare interventions: explanation and elaboration. $B M J$ 2009;339:b2700. doi: 10.1136/bmj.b2700

3. Lopman, B, Liu, CY, Guillou, AL, et al. A model of COVID-19 transmission and control on university campuses. medRxiv preprint $2020 \mathrm{doi}$ : https://doi.org/10.1101/2020.06.23.20138677 4. J Massey Cashore, Ning Duan, Alyf Janmohamed, et al. COVID-19 Mathematical Modeling for Cornell's Fall Semester. 2020 Available from:

https://people.orie.cornell.edu/pfrazier/COVID_19_Modeling_Jun15.pdf

5. Gressman, PT, Peck, JR. Simulating COVID-19 in a University Environment. arXiv preprint 2020 doi: Available from: https://arxiv.org/abs/2006.03175

6. Martin, NK, Schooley, RT, Gruttola, VD. Modelling testing frequencies required for early detection of a SARS-CoV-2 outbreak on a university campus. medRxiv preprint 2020 doi: https://doi.org/10.1101/2020.06.01.20118885

7. Virtual Forum for Knowledge Exchange in the Mathematical Sciences (V-Kems). Unlocking Higher Education Spaces - What Might Mathematics Tell Us? Working Paper. Available from: https://gateway.newton.ac.uk/sites/default/files/asset/doc/2007/Unlocking\%20HE\%20Spaces\%20July \%202020_small_0.pdf

8. Department of Health and Social Care. NHS Test and Trace statistics 28 May to 12 August 2020: data tables. [updated 20 August 2020]. Available from:

https://assets.publishing.service.gov.uk/government/uploads/system/uploads/attachment_data/file/910 741/NHS_T_T_Statistics_28May_12Aug_DataTables.ods [accessed 24 August 2020].

9. Nussbaumer-Streit, B, Mayr, V, Dobrescu, A, et al. Quarantine alone or in combination with other public health measures to control COVID-19: a rapid review. Cochrane Database of Systematic Reviews 2020(4) doi: 10.1002/14651858.CD013574

10. Huang, C, Liu, X, Sun, S, et al. Insights into the transmission of respiratory infectious diseases through empirical human contact networks. Sci Rep 2016;6:31484. doi: 10.1038/srep31484

11. Karami, M, Doosti-Irani, A, Ardalan, A, et al. Public Health Threats in Mass Gatherings: A Systematic Review. Disaster Med Public Health Prep 2019;13(5-6):1035-46. doi:

10.1017/dmp.2018.161

12. Neal, KR, Nguyen-Van-Tam, JS, Jeffrey, N, et al. Changing carriage rate of Neisseria meningitidis among university students during the first week of term: cross sectional study. BMJ 2000;320(7238):846-9. doi: 10.1136/bmj.320.7238.846

13. Nichol, KL, Tummers, K, Hoyer-Leitzel, A, et al. Modeling seasonal influenza outbreak in a closed college campus: impact of pre-season vaccination, in-season vaccination and holidays/breaks. PLoS One 2010;5(3):e9548. doi: 10.1371/journal.pone.0009548

14. The Independent Scientific Advisory Group for Emergencies (Sage). Independent SAGE-

Behaviour Group Consultation Statement on Universities in the context of SARS-CoV-2. Available from: https://documentcloud.adobe.com/link/review?uri=urn:aaid:scds:US:8606a4a2-9237-4f70-8e8e$\underline{\text { 8a5384a8db39 [accessed } 25 \text { August 2020]. }}$.

15. Limb, M. Covid-19: Sandwell Council in West Midlands sets up contact tracing, citing failures of national scheme. $B M J ; 370: \mathrm{m} 3065$ doi: https://doi.org/10.1136/bmj.m3065

16. Wang, X, Guo, X, Xin, Q, et al. Neutralizing Antibodies Responses to SARS-CoV-2 in COVID19 Inpatients and Convalescent Patients. Clin Infect Dis 2020 doi: 10.1093/cid/ciaa721

17. Jeffrey Seow, Carl Graham, Blair Merrick, et al. Longitudinal evaluation and decline of antibody responses in SARS-CoV-2 infection. medRxiv preprint 2020 doi:

https://doi.org/10.1101/2020.07.09.20148429 